TAPROBANICA, ISSN 1800-427X. June, 2014. Vol. 06, No. 01: pp. 32-45, 1 pl.

(C) Research Center for Climate Change, University of Indonesia, Depok, Indonesia \& Taprobanica Private Limited, Homagama, Sri Lanka http://www.sljol.info/index.php/tapro

\title{
STUDIES ON DIVERSITY, DISTRIBUTION, AND CONSERVATION OF THE BAT FAUNA IN MAHARASHTRA STATE, INDIA
}

\author{
Vishakha S. Korad
}

Department of Zoology, Fergusson College, Pune, Maharashtra, India; E-mail: vishakhakorad@yahoo.com

\begin{abstract}
Maharashtra state is the third largest by area in India. Maharashtra's bat fauna comprises eight families, 23 genera, and 41 species, most of which are insectivorous microchiropterans. Eleven of the 41 bat species are found throughout the state whereas 21 species have few colonies with restricted distribution. Five species endemic to South Asia occur in the state. Maharashtra is separated into six divisions in this paper on the basis of geography, topography, and agro-climatic conditions; the presence of bat species and their roosting sites are reported per division. The IUCN status of bat species is listed, as well as endemism. Types of forests in the state and forest cover in each of the six divisions are considered for discussion in the context of bat distribution. Bat species richness and evenness are compared using the Shannon-Weaver (S-W) Index and Simpson's indices (Reciprocal and Diversity). The results are discussed from the viewpoint of conservation of bat fauna in forest areas in general and the Western Ghats region of the state in particular.
\end{abstract}

Key words: biogeography, Chiroptera, ecology, roosting, species richness, Western Ghats

\section{Introduction}

The mammalian fauna of India was surveyed and results published by the Bombay Natural History Society in the early $20^{\text {th }}$ century. The project accumulated 50,000 specimens over 12 years, especially of the smaller mammals, and the information was published in 47 papers. Robert Charles Wroughton and coworkers reported region-wide data of mammalian species including from Order Chiroptera. For the bats, the contributions of Brosset (1962a-c) and Khajuria (1953), based on their fieldwork in central and western India in the mid- $20^{\text {th }}$ century, are noteworthy. More recently, Bates and co-workers surveyed Chiroptera in India. Several published studies are also available on the reproductive biology, taxonomy, and distribution of the bats of Maharashtra. The present study is based on the literature available on the diversity and distribution of bat species in the state of Maharashtra available in publications by Ellerman \& Morrison-Scott (1951), Corbet \& Hill (1992), Bates \& Harrison 
(1997), the CAMP Report (2002), Wilson \& Reeder (2005), Simmons (2005), Talmale \& Pradhan (2009), Pradhan \& Talmale (2012), Gaikwad et al. (2012), and others. After delineation of the list of species present and their roosting sites within the state, the most recent IUCN conservation opinions on individual species are considered, local risk factors analyzed, and conservation priorities discussed.

\section{Materials and Methods}

Study area: Maharashtra state has an area of $307,713 \mathrm{~km}^{2}$ and stretches from the central western coast of India to central India. The Western Ghats mountain range, also known as the Sahyādri, runs north-south and constitutes the backbone of the state (Fig. 1). It separates the inland Deccan plateau from the coastal strip of land known as Konkan. The Konkan division is narrow coastal lowland, barely $50 \mathrm{~km}$ wide, which runs along the entire western border of the state. The Konkan alternates between narrow steep-sided valleys and low laterite plateau.

The western aspect of the Western Ghats forms steep cliffs with an average elevation of $1,000 \mathrm{~m}$ but its slopes then gently descend towards the east and south-east. These hills are basaltic in composition but, towards the southern and western sides, the basalt is overlain by laterite. Both basalt and laterite rocks are prone to erosion and cave formation and the caves range from small in size to large. The basalt rocks, in particular, show shallow to deep crevices, depressions of various dimensions and shapes, and high cliffs. Tunnel formations are common and these very often open up into a single chamber or inter-connect several chambers.

Gallery forest is a feature of the Western Ghats and this variety of topography, vegetation, and, consequently, climate makes for rich wildlife habitat and, indeed, bat habitat. The tropical monsoon blows from June to September and precipitation is heavy on the crest of the Sahyādri (average $400 \mathrm{~cm}$ ) and heavier still in the Konkan region. Rainfall in the state declines northwards and diminishes to $70 \mathrm{~cm}$ in the Deccan plateau. Later in the season, the rains increase slightly eastwards in the Marathwada and Vidarbha regions. The Krishna, Bhima, Godavari, Tapi-Purna, and Wardha-Wainganga are the major river systems and have their impact on the ecology of the state.

According to the India State Forest Report, Forest Survey of India (2011), in Maharashtra forest and tree cover comprise about 59,725 $\mathrm{km}^{2}$. Maharashtra's forests run a gamut viz., tropical semi-evergreen forest, tropical moist deciduous forest, tropical dry deciduous forest, tropical thorn forest, littoral and swamp forest, and subtropical broad-leaved hill forest (Champion \& Sheth, 1968). The tropical dry deciduous forest is the most common forest type comprising $57.4 \%$ of forest cover, while tropical thorn forest $(1.02 \%)$ and subtropical broad-leaved hill forest (1.54\%) are uncommon in the state. Several very large cities such as Mumbai, Pune, Aurangabad, and Nagpur are in Maharashtra state and the total human population is about 113 million (2011).

Data collection and analysis: Maharashtra was categorized into six divisions for the purpose of our data collection and analysis on the basis of the geographical position, topography, and agro-climatic conditions. Divisions of the state (Fig. 2) were as follows:

\begin{tabular}{|c|c|c|}
\hline Division & Talukas (Subdivision) & Region \\
\hline Nashik & $\begin{array}{l}\text { Nandurbar, Dhule, } \\
\text { Jalgaon, Nashik, } \\
\text { Ahmadnagar }\end{array}$ & - \\
\hline Pune & $\begin{array}{l}\text { Pune, Satara, Sangli, } \\
\text { Kolhapur, Solapur }\end{array}$ & - \\
\hline Konkan & $\begin{array}{l}\text { Thane, Mumbai city, } \\
\text { Mumbai suburbs, } \\
\text { Raigad, Ratnagiri, } \\
\text { Sindhudurg }\end{array}$ & - \\
\hline Aurangabad & $\begin{array}{l}\text { Aurangabad, Jalna, } \\
\text { Parbhani, Hingoli, } \\
\text { Beed, Nanded, Latur, } \\
\text { Osmanabad }\end{array}$ & Marathwada \\
\hline Amaravati & $\begin{array}{l}\text { Amaravati, Akola, } \\
\text { Buldhana, Washim, } \\
\text { Yavatmal }\end{array}$ & \multirow{2}{*}{ Vidarbha } \\
\hline Nagpur & $\begin{array}{l}\text { Gondia, Bhandara, } \\
\text { Nagpur, Wardha, } \\
\text { Chandrapur, Gadchiroli }\end{array}$ & \\
\hline
\end{tabular}

To compare bat species diversity richness and evenness in each division of the Maharashtra state, two methods were followed: (1) the Shannon-Weaver (S-W) Diversity Index (eH'); and, (2) Simpson's Index (Simpson's Diversity Index, 1-D and Simpson's Reciprocal Index, 1/D).To understand risk factors for the bat fauna and the preference of bat species for particular habitats, types of forests found in the 
state and forest cover in each division of the state were taken into consideration. The results are discussed in order to assign priorities for the conservation of bats in Maharashtra state.

While it is recognized that bat taxonomy has recently undergone great change owing to knowledge obtained from genetic analyses, the old system of Order Chiroptera being divided into sub-Orders Megachiroptera and Microchiroptera is used here because that was the paradigm current during the study. The new sub-Orders Yinpterochiroptera and Yangochiroptera are a mix of the old subOrders and show newly determined relationships. The Yinpterochiroptera include the families Pteropodidae, Rhinolophidae, Rhinopomatidae, Hipposideridae, and Megadermatidae that occur in Maharashtra while the Yangochiroptera take in all the other bat families including the Emballonuridae, Vespertilionidae, Miniopteridae, and Molossidae (Tsagkogeorga et al., 2013). We would also like to point out that although we recognize Rhinolophis cognatus as occurring in Maharashtra (see Korad et al., 2008) most authorities (see, for example, Molur \& Srinivasalu, 2008) delineate the species as occurring only in the Andaman Islands.

\section{Results}

Bat fauna reported from Maharashtra: The total number of bat species reported from the state comes to 41 (Appendix 1). Of this number, four species were from the sub-Order Megachiroptera and they belonged to three genera (Rousettus, Cynopterus, Pteropus) and one family (Pteropodidae). The Microchiroptera were far more taxonomically diverse and were represented in the state by 37 species which belonged to 20 genera and seven families of which the Vespertilionidae had the most number of genera (nine) and species (17) (Appendix 1, Fig. 3).

Of the total of 41 species 34 are of 'Least Concern' (LC) in the IUCN assessment whilst four spp. are 'Near Threatened' (NT), and three species are 'Vulnerable' (VU) (Fig. 4). Five spp. (Hipposideros speoris (Schneider, 1800); H. lankadiva Kelaart, 1850; Scotozous dormeri (Dobson, 1875); Rhinolophus beddomei Andersen, 1905; and R. cognatus (Andersen, 1906) are endemic to South Asia and their conservation status ranges from LC to NT to VU (also see Appendix 1).

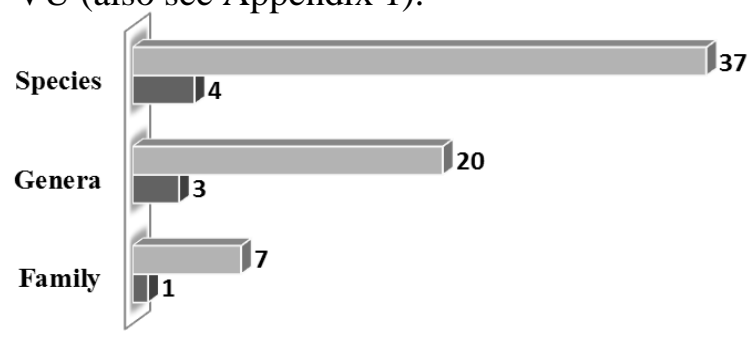

Figure 3: Diversity of bat fauna in Maharashtra state; light gray shows microchiropterans and dark gray shows megachiropterans.

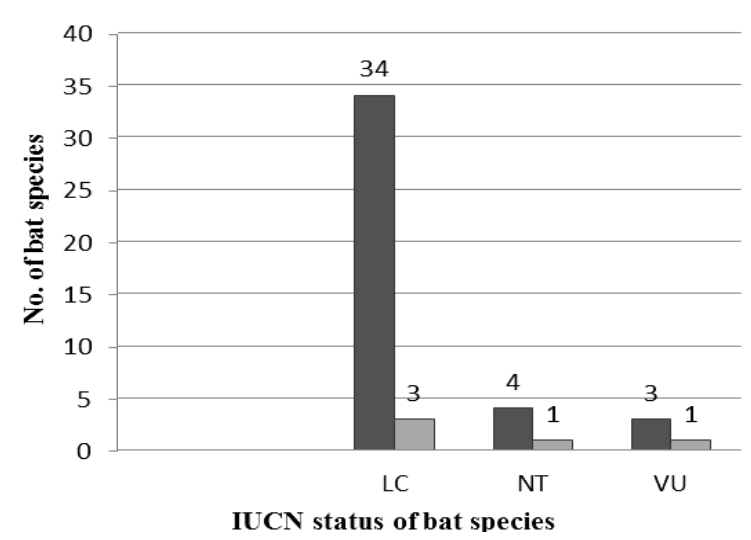

Figure 4: IUCN status of bat species reported from Maharashtra state; dark gray shows the number of bat species and light gray shows number of endemic bat species.

Eleven bat species are 'widely' distributed in Maharashtra (Table 1) which means that these species were found in at least five of the six divisions of the state. Amongst the pteropodids found in Maharashtra the Indian flying fox Pteropus giganteus had the largest number of roost sites. Indeed, the highest number of roost sites for P. giganteus in all of the Indian states is in Maharashtra. The reported numbers of roosting sites of Cynopterus sphinx and Megaderma lyra in Maharashtra state is also remarkably high.

However, of the 41 bat species reported from the state 21 are reported from only one or two divisions; moreover, each of these bat species represent barely $1 \%$ to $2 \%$ of the total number of reported roosting sites in the state (Table 2). For example, Rhinopoma hardwickii is known only from a single division and that, too, from just one roost site. The same goes for Myotis formosus, Myotis montivagus, and Pipistrellus pipistrellus. The horseshoe bat Rhinolophus rouxii and Savi's pipistrelle Hypsugo savii, on the other hand, although confined to the 
Western Ghats, have high numbers of roosting sites although within a relatively small geographic space.

Table 1: Widely distributed bat species of

\begin{tabular}{|c|c|c|c|}
\hline Bat species & 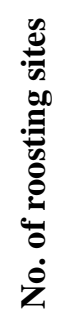 & 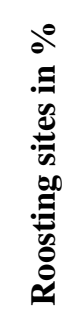 & 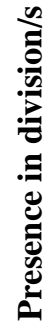 \\
\hline Rousettus leschenaulti & 36 & 6.84 & 5 \\
\hline Pteropus giganteus & 51 & 9.69 & 6 \\
\hline Cynopterus sphinx & 43 & 8.17 & 6 \\
\hline Taphozous longimanus & 20 & 3.8 & 6 \\
\hline Taphozous melanopogon & 11 & 2.1 & 5 \\
\hline Megaderma lyra & 42 & 7.98 & 5 \\
\hline Hipposideros fulvus & 22 & 4.8 & 6 \\
\hline Scotophilus heathii & 28 & 5.32 & 6 \\
\hline Scotophilus kuhlii & 15 & 2.85 & 6 \\
\hline Pipistrellus tenuis & 13 & 2.47 & 6 \\
\hline Pipistrellus ceylonicus & 28 & 5.32 & 6 \\
\hline
\end{tabular}

Maharashtra state

The roosting sites of bat species reported from Maharashtra state are categorized by division (Appendix 1, Figs. 5, 6). This comparison indicates that the highest number of bat species is in Pune division (36 bat species and 54\% of total reported roosting sites in the state). The number of bat species and roosting sites reported from Konkan, Aurangabad, and Nagpur divisions are also relatively high, while the Nashik and Amaravati divisions are relatively poor.

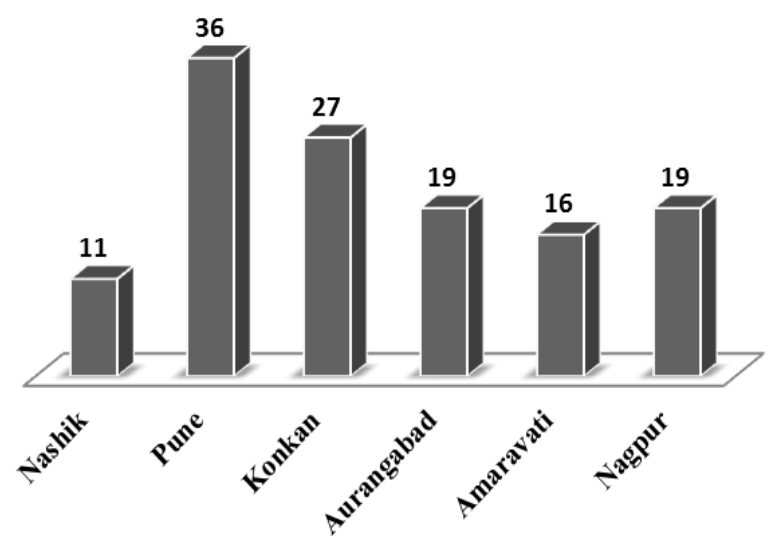

Figure 5: Number of bat species reported from divisions of Maharashtra state

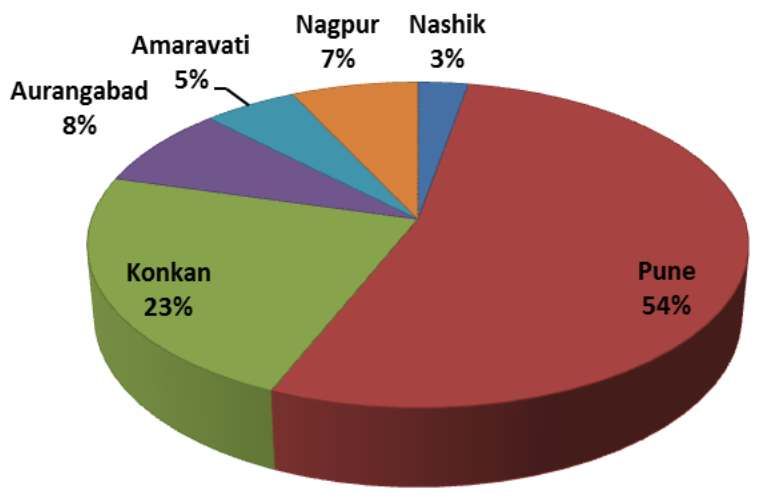

Figure 6: Bat species of Maharashtra state: Locations of bat species reported from divisions

Table 2: Sparsely distributed bat species of Maharashtra state

\begin{tabular}{|c|c|c|c|}
\hline Bat species & 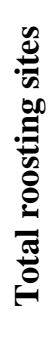 & $b^{0}$ & 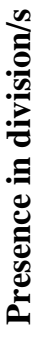 \\
\hline Cynopterus brachyotis & 2 & 0.39 & 1 \\
\hline Rhinopoma hardwickii & 1 & 0.2 & 1 \\
\hline Taphozous nudiventris & 3 & 0.59 & 1 \\
\hline Saccolaimus saccolaimus & 2 & 0.39 & 1 \\
\hline Rhinolophus rouxii & 27 & 5.13 & 2 \\
\hline Rhinolophus cf. cognatus & 4 & 0.76 & 1 \\
\hline Hipposideros pomona & 5 & 0.95 & 2 \\
\hline Hipposideros lankadiva & 3 & 0.57 & 3 \\
\hline Tadarida aegyptiaca & 6 & 1.14 & 2 \\
\hline Chaerephon plicata & 5 & 0.95 & 1 \\
\hline Myotis formosus & 1 & 0.19 & 1 \\
\hline Myotis montivagus & 1 & 0.19 & 1 \\
\hline Myotis horsfieldii & 8 & 1.52 & 2 \\
\hline Pipistrellus pipistrellus & 1 & 0.19 & 1 \\
\hline Pipistrellus javanicus & 5 & 0.95 & 2 \\
\hline Pipistrellus coromandra & 5 & 0.95 & 2 \\
\hline Pipistrellus kuhlii & 3 & 0.57 & 1 \\
\hline Hypsugo savii & 12 & 2.28 & 2 \\
\hline Falsistrellus affinis & 7 & 1.33 & 1 \\
\hline Hesperoptenus tickelli & 6 & 1.14 & 2 \\
\hline Miniopterus schreibersii & 4 & 0.76 & 1 \\
\hline Kerivoula picta & 9 & 1.71 & 2 \\
\hline
\end{tabular}


Maharashtra's bats were further analyzed statistically applying the S-W Index and Simpson's indices such as Reciprocal Index and Diversity Index (Figs. 7, 8). These comparative studies help us understand the 'species richness' (the number of species in a given area, here a division) as well as the 'evenness' (the relative abundance of different species that make up the diversity richness in a given area) of bat species found in various divisions of the state.

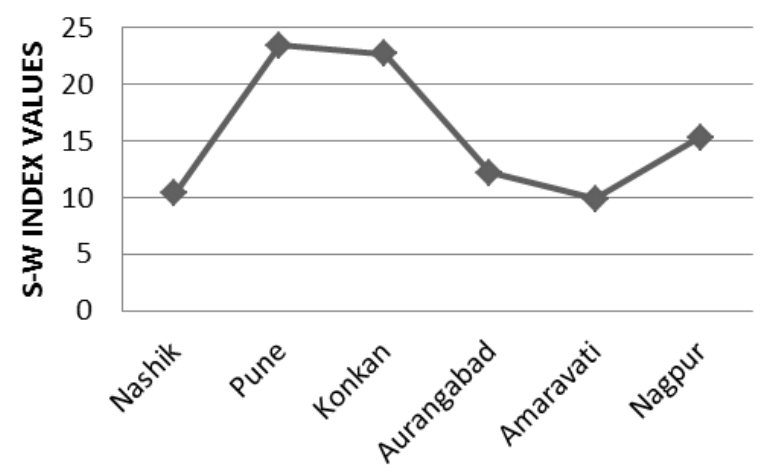

Figure 7: Species diversity and evenness of bat species from divisions of Maharashtra state, analysed using $\mathrm{S}-\mathrm{W}$ index.
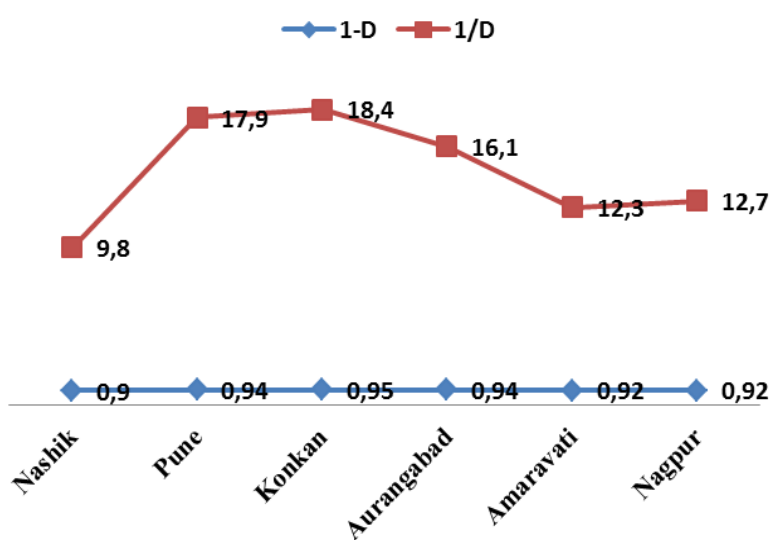

Figure 8: Bat species diversity and evenness analysed using Simpson's indices for divisions of Maharashtra state.

Analyses performed applying the S-W Index for richness and evenness of diversity of bat species in the state indicate that the Pune and Konkan divisions are rich in diversity of bat species and that these species are distributed evenly within these divisions. Nagpur division shows moderate values, as does Aurangabad. Amaravati and Nashik divisions show least values and hence are relatively poor in bat species diversity richness and evenness (Figs. 5-7).
Analyses performed after applying Simpson's indices for richness and evenness of the bat species in the state (Fig. 8), both the reciprocal (1/D) and diversity (1-D) indices, indicate similar results. However, the values for richness and evenness of bat species are found to be a little higher in Konkan division as compared to those of Pune division. The results are expressed more effectively in Fig. 8 with Simpson's reciprocal index than with the diversity index.

To understand the trend of distribution of bat fauna in the state of Maharashtra, the habitat preferences shown by bat species are considered for analysis (Fig. 9). Though forest is preferred as the habitat of $80 \%$ of the bats, $60 \%$ are quite at home in urban or semi-urban settings most probably due to abundance of food and the availability of day-roosting sites. About $58 \%$ of bat species are seen to prefer caves as roost sites.

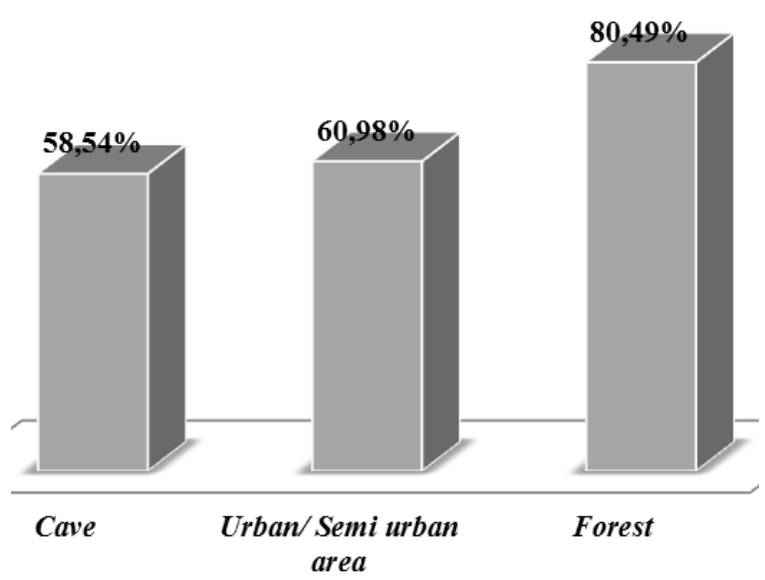

Figure 9: Habitat preference shown by bat species reported from Maharashtra state.

According to the year 2011 state forest report of the Forest Survey of India, very dense forests are found over $8,736 \mathrm{~km}^{2}$ of Maharashtra or just $2.84 \%$ of the area of the state. Moderately dense forest is found over $20,815 \mathrm{~km}^{2}$ or $6.76 \%$ of the area of the state. Non-forest areas, on the other hand, are spread over $252,892 \mathrm{~km}^{2}$ or $82.19 \%$ of the area of Maharashtra. These data indicate a reduction in natural forest areas and increased agricultural planting in urban and suburban areas. In terms of the divisions used in this paper, Konkan and Nagpur are well endowed with forest cover whereas the Aurangabad, Pune, and Nashik divisions have poor forest cover (Fig. 10). 


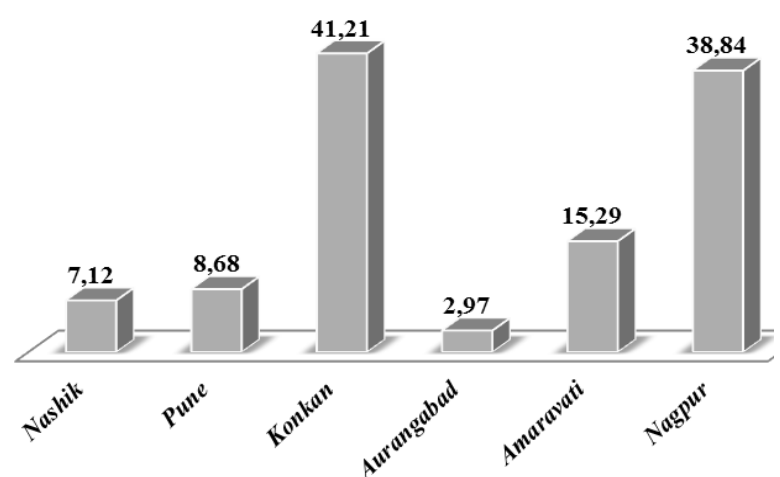

Figure 10: Forest area (\%) calculated on basis of geographic area in divisions of Maharashtra state

\section{Discussion}

The total Indian bat fauna according to Talmale \& Pradhan (2009) includes eight families, 39 genera, 117 species, and 100 subspecies. In this context the diversity of bat fauna in Maharashtra state is high; it shows eight families, 23 genera, and 41 species. Order Chiroptera, to which the bats belong, comprises $31 \%$ of the total mammalian species reported from the state of Maharashtra (Pradhan \& Talmale, 2012).

Twenty of the 41 bat species of Maharashtra are found in less than 10 known roost sites across the entire state and some, such as Pipistrellus pipistrellus, are found in only a single roost. These species, therefore, appear to lead a marginal existence in Maharashtra and deserve urgent conservation attention. According to the mammal survey of the Maharashtra, 28\% of the state's mammal species are comprised of microchiropterans but at present not a single species is protected under the Wildlife (Protection) Act (1972), 2006 (Pradhan \& Talmale, 2012).

Some bat species reported from the state require specialized habitats; for example, the Burmese whiskered bat (Myotis montivagus) which occurs only in the Mahabaleshwar area favours roosting in the vicinity of streams in the hills and feeding on insects in semi-evergreen forest (Korad, et al., 2005). Tickell's bat (Hesperoptenus tickelli) is found at high altitudes and lives singly or in pairs in the foliage of large, densely-leafed euphorbs, agave, mango, and banyan (Phillips, 1980; Mitchell, 1980). The painted bat (Kerivoula picta), reported only from the southern part of Pune division, prefers to roost singly or, occasionally, in pairs in dead, down-hanging dried leaves of wild banana and sugarcane (Phillips, 1980) or even in half-built nests of Baya weaver birds Ploceus philippinus (Sharma, 1986). Because of the specialized habitat requirements of such species they are restricted to the Western Ghats region. The decline in tropical semi-evergreen forest and subtropical broadleaved hill forest in the Western Ghats constitute a major threat to these bats.

On the basis of statistical analyses it is clear that the Pune and Konkan divisions of the state should be the focus of conservation measures because bat species diversity and evenness indices therein are high. Further underlining the need for concern and protection is the fact that the Western Ghats are a globally recognized biodiversity hotspot (Myers, et al., 2000). This Western Ghats ecosystem harbours about 52 bat species nearly $35 \%$ of which are threatened globally or nationally (Korad, et al., 2007). Loss of habitat and habitat fragmentation are the two major contributors to population decline and continuing restriction in distribution of India's bats (Nameer, et al., 2001).

The extent of forest cover in the vicinity of the Western Ghats is variable with Konkan division having the greatest amount of forest and Aurangabad division bringing up the rear (Fig. 10). Thus forests on the western side of the Western Ghats are still in good condition but are much reduced on the eastern side. This has alarming implications not only for the conservation of bats but for other mammal and plant taxa in an acclaimed global biodiversity hotspot. Based on figures in the Forest Survey of India (2011), very dense to moderately dense forest cover covers just $9.6 \%$ of the area of Maharashtra. It is essential then to protect such essential habitat by strong conservation policies, strict enforcement of regulations, and public education.

Chiropterans in Maharashtra by and large favour forest habitats; the many caves in these areas are ideal as roost sites. Unfortunately, these forests are being cut down. About $61 \%$ of the state's bat species, especially hipposiderids, now live in areas of human disturbance showing a high degree of adaptability in these bats. 
Statistical evidence points to a paucity of bat species diversity richness and evenness in Nashik division but this is rather anomalous in that Nashik division is physically near the species-rich Western Ghats; greater effort should be made, therefore, to obtain a clearer picture of bat occurrence and distribution in that division. Similarly, Nagpur division has remarkably high forest cover (38.84\% of area) but a poorly known bat fauna and more surveys are recommended to determine bat species richness in that area.

Cynopterus brachyotis (Muller, 1838), Saccolaimus saccolaimus Temminck, 1838, Rhinolophus rouxii Temminck, 1835, Rhinolophus lepidus Blyth, 1844, Rhinolophus cf. cognatus Andersen, 1906, Hipposideros pomona Andersen, 1918, Myotis montivagus (Dobson, 1874), Pipistrellus pipistrellus (Schreber, 1774), Pipistrellus javanicus (Gray, 1838), Pipistrellus coromandra (Gray, 1838), Pipistrellus kuhlii (Kuhl, 1819), Falsistrellus affinis Dobson, 1871, Hesperoptenus tickelli (Blyth, 1851), and Kerivoula picta (Pallas, 1767) occur exclusively in the Western Ghats and almost all of these bats occupy only a few colonies per species in Maharashtra. Therefore, it is recommended that they be given priority conservation attention regardless of their global IUCN status.

This study shows that Maharashtra is rich in bat species diversity. The particular species richness in the Konkan and Pune divisions of the state, on the western and eastern aspects of the Western Ghats, should make them priorities for conservation efforts. Unfortunately, forest cover in the eastern slopes of the Western Ghats is declining precipitously and requires urgent conservation action to halt terminal decline. It is recommended that more well planned surveys be undertaken in the relatively unexplored Nashik and Nagpur divisions of the state which both show significant potential for harbouring wildlife.

\section{Acknowledgements}

I would like to thank the Head, Department of Zoology, Fergusson College, Pune and the Principal of the college for providing research facilities and encouragement and the Ministry of Environment \& Forests and University Grants Commission (New Delhi) for providing funds. Further I express my gratitude to DFO
(Pune division, Maharashtra), the Director, BMNHS, and Officer-in-Charge ZSI-Western Region for providing library facilities, encouragement, and valuable suggestions.

\section{Literature cited}

Agrawal, V. C. and Y. P. Sinha, 1973. Studies on the bacula of some Oriental bats. Anatomischer Anzeiger, 133: 180-192.

Ali, S., 1953. How long do small bats (Microchiroptera) live? Journal of Bombay Natural History Society, 51: 498-499.

Andersen, K., 1912. Catalogue of the Chiroptera in the collection of the British Museum. Vol. 1: Megachiroptera. British Museum (Natural History), London.

Andersen, K. 1917. On the determination of age in bats. Journal of Bombay Natural History Society, 25: 249-259.

Anonymous, 2006. The Wildlife (Protection) Act, 1972 (As amended upto 2006). Natraj Publishers, Dehra Dun in Technical Association With WWF, Traffic India.

Bastawade, A. D. and A. S. Mahabal, 1976. Some behavioural aspects of the Indian flying fox Pteropus giganteus giganteus. Bio-Vigyanam, 2: 209-212.

Bates, P. J. J. and D. L. Harrison, 1997. Bats of the Indian Subcontinent. Harrison Zoological Museum Publication, Sevenoaks, Kent, UK.

Bates, P.J.J., D. L. Harrison and M. Muni, 1994a. The Bats of Western India revisited. Part I. Journal of Bombay Natural History Society, 91: 1-15.

Bates, P.J.J., D. L. Harrison and M. Muni, 1994b. The Bats of Western India revisited. Part II. Journal of Bombay Natural History Society, 91: 224-240.

Bates, P. J. J., D. L. Harrison and M. Muni, 1994c. The Bats of Western India revisited. Part III. Journal of Bombay Natural History Society, 91: 360-380.

Bhide, S. A. and M. Gupta, 1986. Circadian variation in the alkaline phosphatase activity and total protein content of the alimentary tract and blood glucose of Rousettus leschenaulti and Megaderma lyra. Journal of Animal Morphology \& Physiology, 33: 127-134.

Blanford, W. T., 1888-91. The fauna of British India: Mammalia. Taylor \& Francis, London, UK. 
Brosset, A. 1962a. The bats of central and western India. Part I. Journal of Bombay Natural History Society, 59: 1-57.

Brosset, A. 1962b. The bats of central and western India. Part II. Journal of Bombay Natural History Society, 59: 583-624.

Brosset, A. 1962c. The bats of central and western India. Part III. Journal of Bombay Natural History Society, 59: 707-746.

Champion, H. G. and S. K. Seth, 1968. The forest types of India. Government of India, New Delhi.

Corbet, G. B. and J. E. Hill, 1992. The mammals of the Indomalayan Region: A systematic review. Oxford University Press, Oxford, UK: 488.

D'Abreu, E. A. 1925. The occurrence of Hodgson's bat (Myotis formosus) in the Central Provinces. Journal of Bombay Natural History Society, 30: 905.

Das, P. K and Y. P. Sinha, 1971. Taxonomic and biological notes on the Short-nosed Fruit Bat, Cynopterus sphinx (Vahl) from West Bengal. Proceedings Zoological Society, Calcutta, 24: 157162.

Ellerman, J. R. and T. C. S. Morrison-Scott, 1951. [1966, $2^{\text {nd }}$ Ed.] Checklist of Palaearctic and Indian Mammals 1758-1946. British Museum (Natural History) London.

Gaikwad, M. C., 2007. Study on diversity and habitat preferences of cave bats (Chiroptera) in the central Western Ghats of Maharashtra. Ph.D. Thesis University of Pune, through Department of Zoology, Fergusson College, Pune.

Gaikwad, M. C., S. S. Narwade, K. M. Fartade, and V. S. Korad, 2012. A review of the distribution of bats in South-Western region of Deccan, Maharashtra-India and conservation recommendations. Taprobanica, 4: 27-36.

Ghosh, M. K., 2005. Catalogue of Chiroptera in the collection of the Zoological Survey of India, Part I: Megachiroptera. Records of Zoological Survey of India, Occasional Paper No. 232.

Gopalakrishna, A., 1954. Breeding habits of the Indian sheath tailed bat Taphozous longimanus (Hardwicke). Current Science, 23: 60-61.

Gopalakrishna, A., 1986. Migratory pattern of some Indian bats. Myotis, 23\&24: 223-227.
Gopalakrishna, A. and A. Madhavan, 1970. Sex ratio in some Indian bats. Journal of Bombay Natural History Society, 16: 852-854.

Gopalakrishna, A. and A. Madhavan, 1977. Breeding habits and associated phenomena in some Indian bats Part 3 - Hipposideros ater ater (Templeton) - Hipposideridae. Journal of Bombay Natural History Society, 74: 511-517.

Gopalakrishna, A. and D. Bhatia, 1982. Breeding habits and associated phenomenon in some Indian bats. Part VII- Hipposideros speoris (Schneider) (Hipposideridae) from Chandrapur, Maharashtra. Journal of Bombay Natural History Society, 79: 549-556

Gopalakrishna, A. and N. Badwaik, 1989. Breeding habits and association phenomena in some Indian bats at different latitudes. Part 12-Megaderma lyra lyra (Geoffroy). Journal of Bombay Natural History Society, 86:42-45.

Gopalakrishna, A., A. Madhavan, and N. Badwaik, 1991. Breeding biology of the Indian leaf-nosed bat Hipposideros speoris (Schneider) with notes on its ecology in Marathwada, Maharashtra State. Mammalia, 55: 275-283.

Hill, J. E., 1976. Further records of Myotis peshwa (Thomas, 1915) (Chiroptera: Vespertilionidae) from the Indian Peninsula. Journal of Bombay Natural History Society, 73: 433-437.

Hill, J. E., 1977. A review of the Rhinopomatidae (Mammalia: Chiroptera). Bulletin of the Natural History Museum (Zoology), 32: 29-43.

Karim, K. B. 1975. Early development of the embryo and implantation in the Indian vespertilionid bat, Pipistrellus mimus mimus (Wroughton). Journal of Zoological Society, India, 27: 119-136.

Karim, K. B. and N. Gupta, 1986. A case of superfetation in the Indian fruit bat, Rousettus leschenaultii (Desmarest). Bat Research News, 27: 13-14.

Khajuria, H. 1953. Taxonomic studies on some Indian Chiroptera. Records of Indian Museums, 50: 113-128.

Korad, V. S., 2005. Assessment of Bat Fauna in the Central Western Ghats of Maharashtra (20022005). Report submitted to Government of India, Ministry of Environment \& Forests.

Korad, V. S., 2009. Diversity of Bat Species in Western Ghats around Pune District. Proceedings UGC-sponsored National Conference "Climate 
change and challenges in Biodiversity Conservation": 69-77.

Korad, V. S. and K. D. Yardi, 2004a. Ecological study and faunistic survey of bats from Pune Corporation limits, Maharashtra State, India. Records of Zoological Survey of India, Occasional Paper No. 102: 115-136.

Korad, V. S. and K. D. Yardi, 2004b. New records of bats from Central Western India. Records of Zoological Survey of India, Occasional Paper No. 103: 171-177.

Korad, V. S and M. C. Gaikwad, 2008. About frugivorous bats of Northern Western Ghats. Bat Net-CCINSA Newsletter, 9: 9-11.

Korad, V. S., M. C. Gaikwad, and K. D. Yardi, 2005. Extension in the distribution of Burmese whiskered bat, Myotis montivagus (Dobson, 1874) in the Northern Western Ghats range, Maharashtra, India. Records of Zoological Survey of India, Occasional Paper No. 104: 91-97.

Korad, V. S., M. C. Gaikwad, and A. L. Koratkar, 2006. Record of composite bat colonies in Robber's cave area of Mahabaleshwar region, Maharashtra state, India. Ecology, Environment \& Conservation, 12: $743-748$

Korad, V. S., K. D. Yardi, and R. N. Raut, 2007. Diversity and distribution of bats in Western Ghats. Zoo's Print, 22: 2752-2758.

Korad, V. S., R. Raut, and M. S. Pradhan, 2008. Morphometrics of the Genus Rhinolophus from Western Ghats of Maharashtra. Biosystematica, 2: 33-40.

Korad, V. S., M. C. Gaikwad, and A. L. Koratkar, 2010. Study on diversity, distribution and habitat preference of bat species in Pune District, Maharashtra. Records of Zoological Survey of India, Occasional Paper No. 311: 1-52.

Korad V. S., R. N. Raut, and M. S. Pradhan, 2010. Morphometrics of the genus Hipposideros from Northern Western Ghats of Maharashtra. Biosystematica, 4: 31-38.

Madhavan, A. 1971. Breeding habits in the Indian vespertilionid bat, Pipistrellus ceylonicus chrysothrix (Wroughton). Mammalia, 35: 283-306.

Madhavan, A., 978. Breeding habits and associated phenomena in some Indian bats. Part 5- Pipistrellus doemeri (Dobson) - Vespertilionidae. Journal of Bombay Natural History Society, 75: 426-433.
Madhavan, A., D. R. Patil, and A. Gopalakrishna, 1978. Breeding habits and associated phenomena in some Indian bats. Part 4: Hipposideros fulvus fulvus (Gray) - Hipposideridae. Journal of Bombay Natural History Society, 75: 96-103.

McCann, C. 1934. Notes on the Flying Fox (Pteropus giganteus Brunn.). Journal of Bombay Natural History Society, 37: 143-149.

Mitchell, R. M., 1980. New records of bats (Chiroptera) from Nepal. Mammalia, 44: 339-342.

Modak, S. P. and D. N. Kamat, 1968. A study of periodic acid Schiff material in the ovarian follicles of tropical bats. Cytologia, 33: 54-59.

Moghe, M. A., 1951. Development and placentation of the Indian Fruit bat, Pteropus giganteus giganteus (Brunn.). Proceedings of Zoological Society, London, 121: 703-721.

Molur, S., G. Marimuthu, C. Srinivasulu, S. Mistry, A. M. Hutson, P. J. J. Bates, S. Walker, K. P. Priya, and A. R. B. Priya (Eds.)., 2002. Status of South Asian Chiroptera: Conservation Assessment and Management Plan (C.A.M.P.). Workshop Report. Zoo Outreach Organization, CBSG South Asia and WILD, Coimbatore, India: 320.

Molur, S. \& Srinivasulu, C. 2008. Rhinolophus cognatus. In: IUCN 2013. IUCN Red List of Threatened Species. Version 2013.2.

Muni, M., A. Kothari, and D. A. Bhiwgade, 1994. Occurrence of the leaf-nosed bat Hipposideros lankadiva Kelaart (Mammalia : Chiroptera : Rhinolophidae) in Ratnagiri district, Maharashtra. Journal of Bombay Natural History Society, 91: 136-137.

Myers, N., R. A Mittermeier, C. G Mittermeier, G. A. B. da Fonesca, and J. Kent, 2000. Biodiversity hotspots for conservation priorities. Nature, 403: 853-858.

Naidu, T. S. V. and B. M. Murhar, 1979. On the occurrence of Spinostrongylus indicus Loekar, 1970 (Nematoda: Trichostrongylidae) in two micro-bats (new hosts) from Nagpur and a note on copulation. Current Science, 48: 463-464.

Naidu, T. S. V. and V. K. Thakare, 1980. On Rictularia patwardhani n. sp. From intestine of Megaderma lyra (Geoffroy) and Taphozous melanopogon (Temminck) of Nagpur, India. Revista Parasitologica, 41: 101-104. 
Nameer, P. O., S. Molur, and S. Walker, 2001. Mammals of Western Ghats: A simplistic overview. Zoo's Print, 16: 629-639.

Pathak, S. and T. Sharma, 1969. Chromosomes of five species of Indian vespertilionid bats. Cytologia, 22: $35-46$.

Phillips, W. W. A., 1980. Manual of Mammals of Sri Lanka. Part I. Wildlife \& Nature Protection Society of Sri Lanka.

Pradhan, M. S. 2004. Mammalia. In: Fauna of Pench National Park (Maharashtra). Conservation Area Series, Zoological Survey of India, Kolkata, 20: 960 .

Pradhan, M. S. 2005. Mammalia. In: Fauna of Melghat Tiger Reserve. Conservation Area Series, Zoological Survey of India, Kolkata, 24: 11-113.

Pradhan, M. S. 2006. Mammalia. In: Fauna of Tadoba-Andhari Tiger Reserve (Maharashtra). Conservation Area Series, Zoological Survey of India, Kolkata, 25: 11-63.

Pradhan, M. S. and P. P. Kulkarni, 1997. Observations on the extended distribution of Cynopterus brachyotis ceylonensis Gray in Western India with comments on its status. Mammalia, 61: 116-118.

Pradhan, M. S. and S. S. Talmale, 2008. Mammalia, In: Fauna of Lonar Wildlife Sanctuary. Conservation Area Series, Zoological Survey of India, Kolkata, 37: 17-28.

Pradhan, M. S. and S. S. Talmale, 2012. Mammalia. In: Fauna of Maharashtra, State Fauna Series, Zoological Survey of India, Kolkata, 20: 21-145.

Ray-Chaudhari, S. P., S. Pathak, and T. Sharma, 1971. Karyotypes of five Indian species of Microchiroptera. Caryologia, 24: 239-245.

Sabnis, J. H., 1973. Studies on the post-partum involution of the uterus of some Indian bats. Revue Roumaine de Biologie, 18: 49-55.

Sapkal, V. M. and W. R. Bhandarkar, 1984. Breeding habits and associated phenomena in some Indian bats. Part IX- Hipposideros lankadiva (Kelaart)-Hipposideridae. Journal of Bombay Natural History Society, 81: 380-386.

Sapkal, V. M. and K. G. Khamre, 1984. Breeding habits and associated phenomenon in some Indian bats. Part 8- Taphozous melanopogon (Temminck)Emballonuridae. Journal of Bombay Natural History Society, 80: 303-311.
Shannon, C.E. and W. Weaver, 1949. The Mathematical Theory of Communication. University of Illinois Press, Urbana, IL, USA.

Sharma, S. K., 1986. Painted bats and nests of Baya Weaver bird. Journal of Bombay Natural History Society, 83: 196.

Simmons, N. B., 2005. Order Chiroptera. In: Wilson, D. E. and D. M. Reeder (Eds.). Mammal species of the World: a taxonomic and geographic reference, Third Ed., Vol. 1. Johns Hopkins Univ. Press, Baltimore, MD, USA: 312-529.

Simpson, E. H. 1949. Measurement of diversity. Nature, 163: 688.

Sinha, Y. P., 1980. The bats of Rajasthan; taxonomy and zoogeography. Records of Zoological Survey of India, 76: 7-63.

Talmale, S. S. 2007. Small mammal diversity in Maharashtra State. Ph. D. Thesis, University of Pune.

Talmale, S. S. and M. S. Pradhan, 2009. A Checklist of Valid Indian Bat Species (Chiroptera: Mammalia). Zoological Survey of India.

Thomas, O. 1897. On some bats obtained in the Surat and Thana districts by Mr. R. C. Wroughton. Journal of Bombay Natural History Society, 11: 274-276.

Thomas, O. 1915. Scientific Results from the Mammal Survey No. X: A. The Indian Bats assigned to the genus Myotis. Journal of Bombay Natural History Society, 23: 607-613.

Tiwari, K. K., R. K. Ghose, and S. Chakraborty, 1971. Notes on a collection of small mammals from Western Ghats, with remarks on the status of Rattus rufescens (Gray) and Bandicota indica malabarica (Shaw). Journal of Bombay Natural History Society, 68: 378-384.

Topal, G. 1974. Field observations on Oriental bats. Sex ratio and reproduction. Vertebrata Hung, 15: 83-94.

Topal, G., 1975. Bacula of some Old World Leafnosed bats (Rhinolophidae and Hipposideridae, Chiroptera: Mammalia). Vertebrata Hungarica, 15: 21-45.

Tsagkogeorga, G., J. Parker, E. Stupka, J. A. Cotton, S. J. Rossiter, 2013. Phylogenomic analyses elucidate the evolutionary relationships of bats (Chiroptera). Current Biology, 23: 2262-2267 
Wilson, D. E. and D. M. Reeder (Eds.)., 2005. Mammal Species of the World, $3^{\text {rd }}$ Edition, Johns Hopkins University Press, Baltimore, MD.

Wroughton, R. C., 1912a. Report No. 1: East Khandesh. Bombay Natural History Society's Mammal Survey of India. Journal of Bombay Natural History Society, 21: 391-410.

Wroughton, R. C., 1912b. (i) Report No. 2: Berars [820-825]; [ii] Report No. 3: Cutch [826-844]; [iii] Report No. 4: Nimar [844-851]. Bombay Natural History Society's Mammal Survey of India. Journal of Bombay Natural History Society, 21: 820-851.

Wroughton, R. C., 1912c. Report No. 5: Dharwar [844-851]. Bombay Natural History Society's Mammal Survey of India. Journal of Bombay Natural History Society, 21: 1170-1195.

Wroughton, R. C., 1913. Report No. 6: Kanara. Bombay Natural History Society's Mammal Survey of India. Journal of Bombay Natural History Society, 22: 29-44.
Wroughton, R. C., 1916. [i] Report No. 20: Chindwin River [291-309]; [ii] Report No. 21: Gwalior [309-310]; [iii] Report No. 22: Koyna Valley [311-316]. Bombay Natural History Society's Mammal Survey of India. Journal of Bombay Natural History Society, 24: 291-316.

Wroughton, R. C. and K.V. Ryley, 1913. Bombay Natural History Society's Mammal Survey of India. Report No. 7: [Central Provinces]. Journal of Bombay Natural History Society, 22: 45-58.

Wroughton, R. C. and W. M. Davidson, 1920. Bombay Natural History Society's Mammal Survey of India. Report No. 30: [Dekhan, Poona District]. Journal of Bombay Natural History Society, 26: 1025-1030.

Yazdani, G. M., M. S. Pradhan, and D. F. Singh, 1992. Fauna of Conservation Areas: Fauna of Sanjay Gandhi National Park, Bombay (Vertebrates). Records of Zoological Survey of India, 92: 225-251.

\section{Appendix I: Bat species of Maharashtra state}

Species

Recorded locations in the state of Maharashtra

\section{Sub-Order Megachiroptera}

\section{Family Pteropodidae (Old World fruit bats)}

Ghatmatha (Wroughton, 1916); Chikhalda, Elephanta, Jogeshwari, Kanheri,

Khandara, Alibag, Aurangabad, Ratnagiri (Brosset, 1962a); Ellora (Brosset, 1962a; Bates et al., 1994a); Mahabaleshwar (Brosset, 1962a; Korad, 2005; Korad et al., 2006; Korad \& Gaikwad, 2008; Korad, 2009); Marathwada (Gopalakrishna \& Madhavan, 1970); Satara (Agrawal \& Sinha, 1973); Kandri

Rousettus leschenaulti (Desmarest, 1820) ${ }^{\mathrm{LC}}$

Pteropus giganteus Brunnich, $1782^{\mathrm{LC}}$

Cynopterus sphinx (Vahl, 1797) ${ }^{\mathrm{LC}}$
Mines (Karim \& Gupta, 1986); Mansar (Bhide \& Gupta, 1986); Pune (Bates \& Harrison, 1997); Khindsi (Ghosh, 2005); Maval, Mulshi, Junnar, Bhor, Saswad; Khopoli, Wai, Raigad (Korad, 2005); Malshej Waterfall, Lonavala (Gaikwad, 2007); Sinhgad, Purandar, Mendha village, Lakhani (Talmale, 2007); Lonar Crater \& Wildlife Sanctuary (Pradhan \& Talmale, 2008); Phaltan, Mangalvedha, Kegaon road, Naldurg Fort, Paranda Fort (Gaikwad et al., 2012). Pili Sipna Valley (Wroughton, 1912b, Pradhan, 2005); Asirgarh, Siwal (Wroughton, 1912b); Karla, Patan (Wroughton, 1916); Poona (Wroughton \& Davidson, 1920; Korad \& Yardi, 2004a; Korad et al., 2006; Korad \& Gaikwad, 2008; Korad et al., 2010a); Ahmednagar, Bombay, Malad, Thane, Belapur, Kalyan (McCann, 1934); Amravati (Moghe, 1951); Nagpur (Moghe, 1951; Talmale, 2007); Satara (Bastawde \& Mahabal, 1976); Chandrapur, Chanda (Sinha, 1980); Sanjay Gandhi NP, Borivali (Yazdani et al., 1992); Pench NP (Pradhan, 2004); Junnar, Khed, Maval, Mulshi, Haveli, Shirur, Daund, Indapur, Saswad, Velhe, Bhor, Poladpur, Raigad (Korad, 2005; Korad \& Gaikwad, 2008); Deola, Usgaon village, Gadkhangaon, Amalner (Talmale, 2007); Natepute, Akluj, Malinagar, Maloli, Bhalvani, Pandharpur, Rambaug, Tembhurni, Karmala, Barshi, Pangaon, Solapur, Kati, Sindfal, Kini, Jagji, Mangalvedha (Gaikwad et al., 2012).

Nashik (Andersen, 1912); Poona (Wroughton \& Davidson, 1920; Korad \& Yardi, 2004a), Chanda (Wroughton, 1913i); Nagpur (Das \& Sinha, 1971); Bandra (Andersen, 1912; Yazdani et al., 1992); Sanjay Gandhi NP, Borivali (Yazdani et al., 1992); Ajanta (Bates et al., 1994a); Pench NP (Pradhan, 2004); Mulshi, Velhe, Junnar, Bhor, Saswad; Malshej (Korad, 2005; Korad et al., 2006; Gaikwad, 2007; Korad \& Gaikwad, 2008); Dhakna, Semadoh in Melghat 
TR (Pradhan, 2005); Tadoba-Aandhari TR (Pradhan, 2006); Lakhani, Nalganga, Khandala (Talmale, 2007); Dimbhe, Supe, Patas, Daund, Nimbalak, Baramati, Natepute, Indapur, Karmala, Nira-Narsingpur, Malshiras, Malinagar, Tembhurni, Maloli, Bhalavani, Pandharpur, Mangalvedha, Solapur, Kati, Pangaon, Barshi, Kini, Jagji, Osmanabad (Gaikwad et al., 2012).

$\begin{aligned} & \text { Cynopterus brachyotis } \\ & \text { (Muller, 1838) }\end{aligned}$
LC $\quad$ Khandala, Mahabaleshwar (Pradhan \& Kulkarni, 1997).

\begin{tabular}{|c|c|}
\hline \multirow{2}{*}{\multicolumn{2}{|c|}{ Sub-Order Microchiroptera }} \\
\hline & \\
\hline $\begin{array}{l}\text { Rhinopoma microphyllum } \\
\text { (Brunnich, 1782) } \mathrm{LC}\end{array}$ & $\begin{array}{l}\text { Bombay (Hill, 1977); Nagpur (Sinha, 1980); Osmanabad (Khajuria, 1953; } \\
\text { Gopalakrishna, 1986); Songir, Bhamer (Bates \& Harrison, 1997); Apsinga, } \\
\text { Tuljapur, Naldurg Fort (Gaikwad et al., 2012). }\end{array}$ \\
\hline $\begin{array}{l}\text { Rhinopoma hardwickii } \\
\text { Gray, } 1831 \text { LC }\end{array}$ & Tadoba-Andhari TR (Pradhan, 2006). \\
\hline \multicolumn{2}{|c|}{ Family Emballonuridae (Sheath-tailed bats) } \\
\hline $\begin{array}{l}\text { Taphozous longimanus } \\
\text { Hardwicke, } 1825 \text { LC }\end{array}$ & $\begin{array}{l}\text { Chanda (Wroughton, 1913); Chandrapur (Wroughton \& Ryley, 1913); Khed } \\
\text { (Wroughton, 1916); Nagpur, Amaravati (Gopalakrishna, 1954); Arnala, } \\
\text { Elephanta; Khandala, Ratnagiri (Brosset, 1962a); Raigad Fort area, Karjat } \\
\text { (Korad, 2005; Korad et al., 2010a); Wadgaon (Talmale, 2007); Lonar (Pradhan } \\
\text { \& Talmale, 2008); Patas, Dhamangaon, Solapur, Osmanabad, Apsinga, } \\
\text { Naldurga, Ahmednagar, (Gaikwad et al., 2012). }\end{array}$ \\
\hline $\begin{array}{l}\text { Taphozous melanopogon } \\
\text { Temminck, } 1841^{\mathrm{LC}}\end{array}$ & $\begin{array}{l}\text { Narnala (Wroughton, 1912; Sapkal \& Khamre, 1984); Chikalda in Melghat TR } \\
\text { (Wroughton, 1912; Pradhan, 2005); Kanheri caves in Sanjay Gandhi NP, Ellora, } \\
\text { Pittalkora, Alibag (Brosset, 1962a); Aurangabad (Ray-Chaudhari et al., 1971); } \\
\text { Nagpur (Naidu \& Thakare, 1980); Daulatabad, Helwak, Rajpur (Bates \& } \\
\text { Harrison, 1997). }\end{array}$ \\
\hline $\begin{array}{l}\text { Taphozous nudiventris } \\
\text { Cretzschmer, } 1830^{\mathrm{LC}}\end{array}$ & $\begin{array}{l}\text { Ajanta (Wroughton, 1912; Brosset, 1962a); Aurangabad, Ellora (Brosset, } \\
\text { 1962a); Kharosa caves (Talmale, 2007). }\end{array}$ \\
\hline $\begin{array}{l}\text { Saccolaimus saccolaimus } \\
\text { Temminck, } 1838 \text { LC }\end{array}$ & Mumbai (Brosset, 1962a; Talmale, 2007); Malvan (Talmale, 2007). \\
\hline \multicolumn{2}{|c|}{ Family Megadermatidae (False vampire bats) } \\
\hline $\begin{array}{l}\text { Megaderma lyra } \\
\text { Geoffroy, } 1810^{\mathrm{LC}}\end{array}$ & $\begin{array}{l}\text { Ghodasgaon (Wroughton, 1912a; Brosset, 1962b); Belapur, Chichpalli } \\
\text { (Wroughton \& Ryley, 1913); Ramane Wadi, Khed (Wroughton, 1916); Pune } \\
\text { (McCann, 1934); Powai lake, Ellora, Aurngabad; Ajanta, Aurngabad; Kanheri, } \\
\text { Borivali (Brosset, 1962b); Nashik, Nagpur, Devikop, Ratnagiri (Sinha, 1980); } \\
\text { Bandra (Gopalakrishna \& Badwaik, 1989); Sanjay Gandhi NP (Yazdani et al., } \\
\text { 1992); Vijaydurg (Bates \& Harrison, 1997); Pipariya, Ranidoh in Pench NP } \\
\text { (Pradhan, 2004); Chinchani, Khandala-Satara, Bhimashankar, Maval, Junnar, } \\
\text { Panshet, Mulshi, Haveli, Bhor, Rajewadi- Satara; Karjat, Mahad (Korad, 2005; } \\
\text { Gaikwad, 2007; Korad et al., 2010a); Parul village near Mahableshwar, } \\
\text { Samewada village, Lakhani, Sindewahi (Talmale, 2007); Supe, Daund, } \\
\text { Baramati, piliv-Sangola, Bhalavani-Pandharpur, Indapur, Kurbavi-Malshiras, } \\
\text { Bhalavani-Mangalvedha, Pothare-Karmala, Osmanabad (Gaikwad et al., 2012). }\end{array}$ \\
\hline $\begin{array}{l}\text { Megderma spasma } \\
\text { Linnaeus, } 1758^{\mathrm{LC}}\end{array}$ & $\begin{array}{l}\text { Khandala (Brosset, 1962b); Mumbai Suburban Dist.: Kanheri, Sanjay Gandhi } \\
\text { National Park- Borivali (Brosset, 1962b; Topal, 1974; Yazdani et al., 1992); } \\
\text { Thana- Rajpur; Chanda (Bates \& Harrison, 1997); Amaravati Dist.: Tarubanda } \\
\text { in Kolkaz area, Melghat Tiger Reserve (Pradhan, 2005); Mahabaleshwar } \\
\text { (Korad, 2005; Korad, 2009); Kolhapur Dist.: Pundre (Talmale, 2007). }\end{array}$ \\
\hline \multicolumn{2}{|c|}{ Family Rhinolophidae (Horseshoe bats) } \\
\hline $\begin{array}{l}\text { Rhinolophus rouxii } \\
\text { Temminck, } 1835^{\mathrm{NT}}\end{array}$ & $\begin{array}{l}\text { Nerur, Sawantwadi, Asgani (Andersen, 1917); Bassein, Borivli, Vihar Lake, } \\
\text { Jogeshwari, Borivali, Kanheri caves (Brosset, 1962b; Yazdani et al., 1992); } \\
\text { Bhaja caves, Khandala, Lohogad Fort, Karnala (Brosset, 1962b); } \\
\text { Mahabaleshwar (Brosset, 1962b; Topal, 1974; Korad, 2005; Korad et al., 2006; } \\
\text { Korad et al., 2010a); Pune (Modak \& Kamat, 1968); Sangmeshwar (Muni et al., } \\
\text { 1994); Pebkila near Matheran, Koturde (Korad, 2005; Talmale, 2007); } \\
\text { Sinhagad-Pune, Maval, Mulshi, Karjat, Harishchandragad, Bhimashankar, } \\
\text { Raigad Fort, Poladpur, Bajire (Korad, 2005; Korad et al., 2008; Korad et al., } \\
\text { 2010a); Devrukh (Talmale, 2007). }\end{array}$ \\
\hline
\end{tabular}




\begin{tabular}{|c|c|}
\hline $\begin{array}{l}\text { Rhinolophus lepidus } \\
\text { Blyth, } 1844 \text { LC }\end{array}$ & $\begin{array}{l}\text { Helwak (Wroughton, 1916); Kanheri caves, Nashik Road (Brosset, 1962b); } \\
\text { Pundre (Talmale, 2007); Khandala, Lonavla, Lohogad Fort, Karnala, Ratnagiri, } \\
\text { Panchgani, Mahabaleshwar (Brosset, 1962b; Korad et al., 2006; Korad et al., } \\
\text { 2008); Khopoli (Tiwari et al., 1971); Mulshi, Junnar, Bhimashankar, } \\
\text { Mahabaleshwar (Korad, 2005; Korad et al., 2010a). }\end{array}$ \\
\hline $\begin{array}{l}\text { Rhinolophus cognatus } \\
\text { Andersen, } 1906 \mathrm{VU}\end{array}$ & $\begin{array}{l}\text { Khireshwar-Harishchandragad, Bhimashankar, Mulshi, Mahabaleshwar (Korad, } \\
\text { 2005; Korad et al., 2008). }\end{array}$ \\
\hline $\begin{array}{l}\text { Rhinolophus beddomei } \\
\text { Andersen, } 1905^{\mathrm{NT}}\end{array}$ & $\begin{array}{l}\text { Khandala, Karla, Bhaja, Bedsar (Brosset, 1962b); Nagpur (Naidu \& Murhar, } \\
\text { 1979); Ramgad (Bates \& Harrison, 1997); Junnar, Maval, Mulshi, Mahad, } \\
\text { Mahabaleshwar (Korad, 2005; Korad et al., 2008; Korad et al., 2010a); Salsette } \\
\text { (Talmale, 2007). }\end{array}$ \\
\hline \multicolumn{2}{|c|}{ Family Hipposiderididae (Leaf-nosed bats) } \\
\hline $\begin{array}{l}\text { Hipposideros ater } \\
\text { Templeton, } 1848^{\mathrm{LC}}\end{array}$ & $\begin{array}{l}\text { Marathwada, Dongarkhed, Shirol (Gopalakrishna \& Madhavan, 1977); Nanded } \\
\text { (Bates \& Harrison, 1997); Maval, Ambegaon, Junnar, Karjat, Mahad, Khopoli, } \\
\text { Mahabaleshwar (Korad, 2005; Korad et al., 2010b). }\end{array}$ \\
\hline $\begin{array}{l}\text { Hipposideros fulvus } \\
\text { Gray, } 1838 \text { LC }\end{array}$ & $\begin{array}{l}\text { Shirgaum (Wroughton, 1916iii); Elephanta (Ali, 1953); Panchgani (Khajuria, } \\
\text { 1953; Korad, 2005); Chikalda, Aurangabad, Nashik, Bombay-Vihar Lake, } \\
\text { Karla, Lonaval, Mahabaleshwar, Ratnagiri (Brosset, 1962b); Nagpur (Sabnis, } \\
\text { 1973); Bhaja (Topal, 1974); Nanded, Marathwada (Madhavan et al., 1978); } \\
\text { Bandra (Bates \& Harrison, 1997); Junnar, Ambegaon, Maval, Mulshi, Karjat, } \\
\text { Mahabaleshwar (Korad, 2005; Korad, 2009; Korad et al., 2010b); Pandharpur } \\
\text { (Talmale, 2007). }\end{array}$ \\
\hline $\begin{array}{l}\text { Hipposideros pomona } \\
\text { Andersen, } 1918^{\mathrm{LC}}\end{array}$ & Mulshi, Maval, Junnar, Mahad (Korad, 2005; Korad et al., 2010b). \\
\hline $\begin{array}{l}\text { Hipposideros galeritus } \\
\text { Cantor, } 1846^{\mathrm{NT}}\end{array}$ & $\begin{array}{l}\text { Chikhalda, Ellora, Mumbai- Kanheri, Bedsar Caves (Brosset, 1962b); Ajanta } \\
\text { (Topal, 1975); Shivtharghal near Mahad (Korad, 2005; Korad et al., 2010b). }\end{array}$ \\
\hline $\begin{array}{l}\text { Hipposideros speoris } \\
\text { (Schneider, 1800) }^{\text {LC }}\end{array}$ & $\begin{array}{l}\text { Chanda (Blanford, 1988-91); Alibag, Borivali, Kanheri (Brosset, 1962b); Pune, } \\
\text { Khandala (Brosset, 1962b; Korad \& Yardi, 2004a); Elephanta (Topal, 1974); } \\
\text { Near Satara (Hill, 1976); Chandrapur (Gopalakrishna \& Bhatia, 1982); Nanded } \\
\text { (Gopalakrishna et al., 1991); Ellora (Bates et al., 1994c); Bhuleshwar, Yavat } \\
\text { (Korad, 2005; Talmale, 2007); Bhimanagar, Indapur, Nira Narsingpur, Bhaje, } \\
\text { Karle, Karjat, Junnar, Shirur; Matheran (Korad, 2005, Korad et al., 2010b; } \\
\text { Gaikwad, 2007); Pothare, Karmala, Bhalavani, Pandharpur, Osmanabad caves, } \\
\text { Kurduwadi (Gaikwad et al., 2012). }\end{array}$ \\
\hline $\begin{array}{l}\text { Hipposideros lankadiva } \\
\text { Kelaart, } 1850 \text { LC }\end{array}$ & $\begin{array}{l}\text { Chandrapur (Sapkal \& Bhandarkar, 1984); Sangameshwar (Muni et al., 1994); } \\
\text { Tadoba-Andhari TR (Pradhan, 2006). }\end{array}$ \\
\hline \multicolumn{2}{|c|}{ Family Molossidae (Free-tailed bats) } \\
\hline $\begin{array}{l}\text { Tadarida aegyptiaca } \\
(\text { Geoffroy, 1818) }\end{array}$ & $\begin{array}{l}\text { Aurangabad (Brosset, 1962c); Pune (Korad \& Yardi, 2004a); Khondai, Mulshi } \\
\text { (Korad, 2005; Korad et al., 2010a); Sinhagad (Talmale, 2007); Dhamangaon, } \\
\text { Solapur, Kunthalgiri, Osmanabad (Gaikwad et al., 2012). }\end{array}$ \\
\hline $\begin{array}{l}\text { Chaerephon plicata } \\
\text { (Buchanan, 1800) } \mathrm{LC}\end{array}$ & $\begin{array}{l}\text { Karla (Bates \& Harrison, 1997); Pune (Korad \& Yardi, 2004a); Patas, Daund, } \\
\text { Lonavla (Korad, 2005; Korad et al., 2010a). }\end{array}$ \\
\hline \multicolumn{2}{|c|}{ Family Vespertilionidae (Vesper or Evening bats) } \\
\hline $\begin{array}{l}\text { Myotis formosus } \\
\text { (Hodgson, 1835) }\end{array}$ & Nagpur (D’Abreu, 1925). \\
\hline $\begin{array}{l}\text { Myotis montivagus } \\
\text { (Dobson, 1874) }\end{array}$ & Mahabaleshwar (Korad et al., 2005). \\
\hline $\begin{array}{l}\text { Myotis horsfieldii } \\
\text { (Temminck, 1840) LC }\end{array}$ & $\begin{array}{l}\text { Pune (Thomas, 1915); Elephanta Island (Brosset, 1962c); near Satara (Hill, } \\
\text { 1976); Lonavla, Lonikalbhor, Shirur, Mahad, Mahabaleshwar (Korad, 2005; } \\
\text { Korad et al., 2010a). }\end{array}$ \\
\hline $\begin{array}{l}\text { Scotophilus heathii } \\
\text { Horsfield, } 1831^{\text {LC }}\end{array}$ & $\begin{array}{l}\text { Nagpur, Panchgani (Khajuria, 1953); Thana, Ajanta (Brosset, 1962c); Elephanta } \\
\text { caves (Brosset, 1962c; Topal, 1974); Andheri, Bandra, Chandrapur, Allapalli, } \\
\text { Poona, Dhulia (Bates \& Harrison, 1997); Sillari in Pench NP (Pradhan, 2004); } \\
\text { Semadoh in Melghat TR (Pradhan, 2005); Alandi, Khed-Shivapur, Bhor, Karjat, } \\
\text { Poladpur (Korad, 2005; Korad et al., 2010a; Gaikwad, 2007)); Kolsa in Tadoba- } \\
\text { Andhari TR (Pradhan, 2006); Sindewahi, Nira Narsingpur, Indapur (Talmale, } \\
\text { 2007); Bhima Koregaon, Daund, Nira Narsingpur, Jamb- Indapur, } \\
\text { Dhamangaon, Solapur (Gaikwad et al., 2012). }\end{array}$ \\
\hline
\end{tabular}




\begin{tabular}{|c|c|}
\hline $\begin{array}{l}\text { Scotophilus kuhlii } \\
\text { Leach, } 1821 \text { LC }\end{array}$ & $\begin{array}{l}\text { Pareli (Thomas, 1897), Ajanta, Bhodwad (Wroughton, 1912a); Poona } \\
\text { (Wroughton \& Davidson, 1920; Korad \& Yardi, 2004a); Nagpur, Panchgani } \\
\text { (Khajuria, 1953); Aurangabad, Bombay, Satara (Brosset, 1962c); Chanda, } \\
\text { Sultanpur (Bates \& Harrison, 1997); Sipna river near Semadoh in Melghat TR } \\
\text { (Pradhan, 2005); Khed, Karjat, Mahabaleshwar (Korad, 2005; Korad et al., } \\
\text { 2010a). }\end{array}$ \\
\hline $\begin{array}{l}\text { Pipistrellus pipistrellus } \\
\text { (Schreber, 1774) }{ }^{\mathrm{LC}}\end{array}$ & Pune City (Korad \& Yardi, 2004b). \\
\hline $\begin{array}{l}\text { Pipistrellus javanicus } \\
\text { (Gray, 1838) }\end{array}$ & $\begin{array}{l}\text { Panchgani (Khajuria, 1953); Pune City (Korad \& Yardi, 2004a); Khed, Karjat, } \\
\text { Matheran (Korad, 2005; Korad et al., 2010a). }\end{array}$ \\
\hline $\begin{array}{l}\text { Pipistrellus coromandra } \\
\text { (Gray, 1838) }^{\mathrm{LC}}\end{array}$ & $\begin{array}{l}\text { Mumbai, Phonda (Brosset, 1962c), Bandra (Bates \& Harrison, 1997), Pune } \\
\text { (Korad \& Yardi, 2004a; Korad, 2005; Korad et al., 2010a); Pimpri-Chinchwad } \\
\text { (Talmale, 2007). }\end{array}$ \\
\hline $\begin{array}{l}\text { Pipistrellus tenuis } \\
\text { (Temminck, 1840) } \mathrm{LC}\end{array}$ & $\begin{array}{l}\text { Bhodwad (Wroughton, 1912a); Chikalda (Wroughton, 1912c); Chandrapur, } \\
\text { Chinchpali; Chanda (Wroughton, 1913ii); Ratnagiri (Sinha, 1980); Mumbai, } \\
\text { Karnala (Brosset, 1962c); Pune (Brosset, 1962c; Korad \& Yardi, 2004a; Korad, } \\
\text { 2005; Korad } \text { et al., 2010a); Nanded (Karim, 1975); Mulshi-jambe farm, Wai, } \\
\text { Hiware tank (Talmale, 2007). }\end{array}$ \\
\hline $\begin{array}{l}\text { Pipistrellus ceylonicus } \\
\text { (Kelaart, 1852) }{ }^{\mathrm{LC}}\end{array}$ & $\begin{array}{l}\text { Helwak (Wroughton, 1916); Chikalda, Ajanta, Nasik, Bombay, Satara (Brosset, } \\
\text { 1962c); Junnar (Brosset, 1962c; Korad, 2005; Korad, 2009; Korad et al., } \\
\text { 2010a); Panchgani (Tiwari et al., 1971); Nanded (Madhavan, 1971); } \\
\text { Aurangabad, Nagpur (Sabnis, 1973); Lonawala, Karla (Topal, 1974); Bandra, } \\
\text { Thana, Lanje, Andhari (Bates \& Harrison, 1997); Pune (Brosset, 1962c; Korad } \\
\text { \& Yardi, 2004a); Maval, Mulshi, Ambegaon, Khed, Karjat, Mahad (Korad, } \\
\text { 2005; Korad, 2009; Korad et al., 2010a); Nalganga, Kopargaon, Talegaon- } \\
\text { Dabhade (Talmale, 2007). }\end{array}$ \\
\hline $\begin{array}{l}\text { Pipistrellus kuhlii } \\
\text { (Kuhl, 1819) }^{\mathrm{LC}}\end{array}$ & $\begin{array}{l}\text { Pune City (Korad \& Yardi, 2004b; Korad, 2005; Korad et al., 2010a); Satara, } \\
\text { Nimbalak (Gaikwad et al., 2012). }\end{array}$ \\
\hline $\begin{array}{l}\text { Hypsugo savii (Bonaparte, } \\
\text { 1837) VU }\end{array}$ & $\begin{array}{l}\text { Pune city (Korad \& Yardi, 2004b); Ranjegaon, Mulshi (Korad, 2005; Korad et } \\
\text { al., 2010a); Nimblak, Phaltan, Satara, Kololi, Baramati, Solapur city, Apsinga, } \\
\text { Tuljapur; Osmanabad caves (Gaikwad et al., 2012). }\end{array}$ \\
\hline $\begin{array}{l}\text { Falsistrellus affinis } \\
\text { Dobson, } 1871^{\mathrm{NT}}\end{array}$ & $\begin{array}{l}\text { Nanded (Pathak \& Sharma, 1969); Pune (Korad \& Yardi, 2004a); Dehu, } \\
\text { Bhimashankar, Shivneri, Bhaje, Saswad; Mahabaleshwar (Korad, 2005; Korad } \\
\text { et al., 2010a). }\end{array}$ \\
\hline $\begin{array}{l}\text { Scotozous dormeri } \\
\text { (Dobson, 1875) }\end{array}$ & $\begin{array}{l}\text { Chanda (Blanford, 1888-91); Ajanta (Wroughton, 1912a); Chikalda } \\
\text { (Wroughton, 1912c); Mumbai (Brosset, 1962c); Nanded (Madhavan, 1978); } \\
\text { Bassein (Bates \& Harrison, 1997); Pune (Korad \& Yardi, 2004a); Mulshi } \\
\text { (Korad, 2005; Korad et al., 2010a); Gangakhed, Mandangadh (Talmale, 2007). }\end{array}$ \\
\hline $\begin{array}{l}\text { Hesperoptenus tickelli } \\
\text { (Blyth, 1851) }\end{array}$ & $\begin{array}{l}\text { Mumbai, Pune (Brosset, 1962c); Chahade (Bates \& Harrison, 1997); Andheri, } \\
\text { Salsette, Kamshet (Talmale, 2007). }\end{array}$ \\
\hline $\begin{array}{l}\text { Miniopterus schreibersii } \\
\text { (Kuhl, 1819) }{ }^{\text {LC }}\end{array}$ & $\begin{array}{l}\text { Mahableshwar, Panchgani (Brosset, 1962c; Korad, 2005; Korad et al., 2006; } \\
\text { Korad, 2009; Korad et al., 2010a); Satara (Hill, 1976); New Karanje, Kolhapur } \\
\text { (Talmale, 2007). }\end{array}$ \\
\hline $\begin{array}{l}\text { Kerivoula picta (Pallas, } \\
\text { 1767) }\end{array}$ & $\begin{array}{l}\text { Ghatmatha (Wroughton, 1916a); Mumbai, Borivali, Khandala, Satara (Brosset, } \\
\text { 1962c); Santacruz, Juhu, Goregaon, Dahanu (Talmale, 2007). }\end{array}$ \\
\hline
\end{tabular}

Abbreviations: EN, Endangered; LC, Least Concern; NE, Not Evaluated; NT, Near Threatened; VU, Vulnerable; NP, National Park; TR, Tiger Reserve. 


\section{PLATE 9}

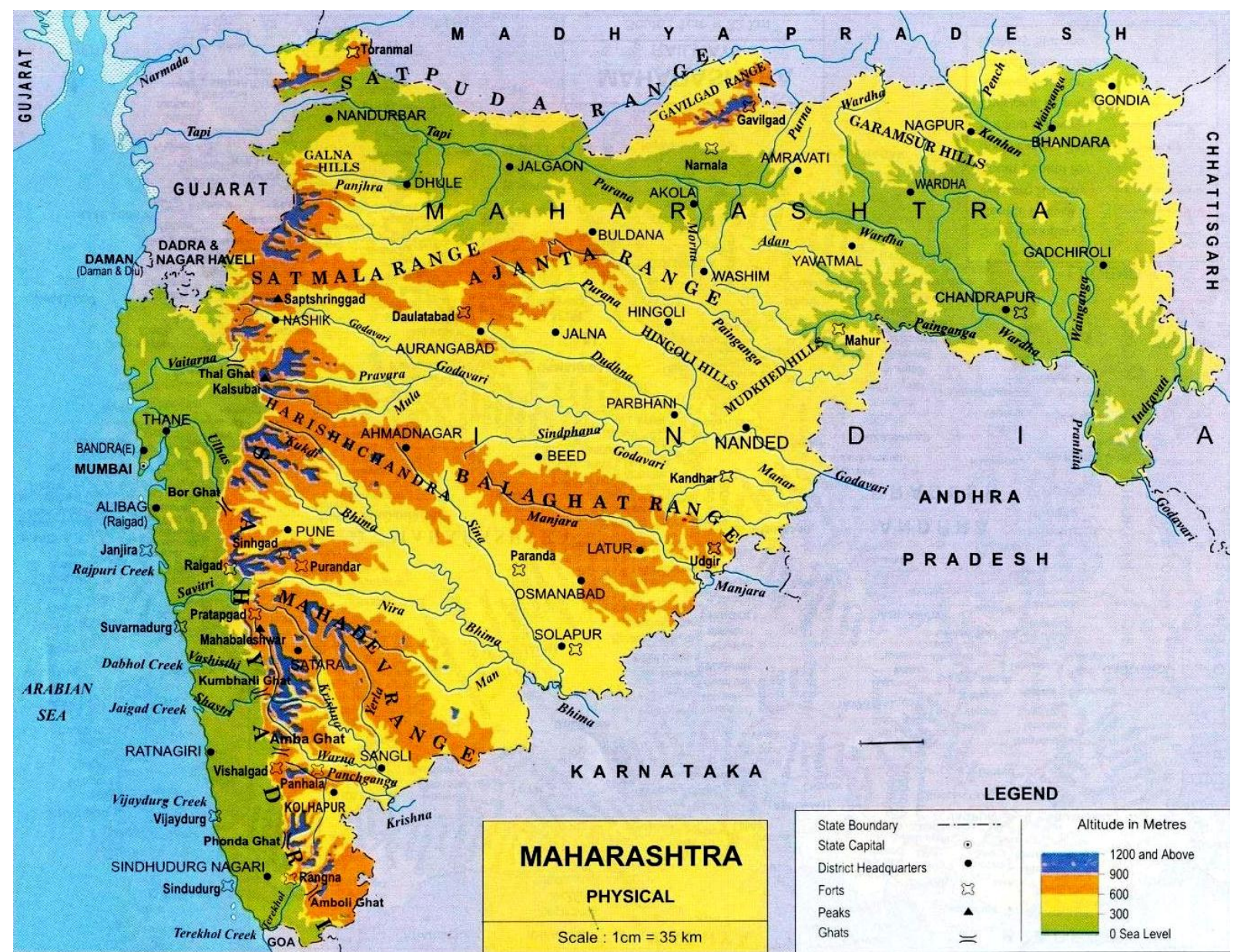

Figure 1: Topographic map of Maharashtra State, India

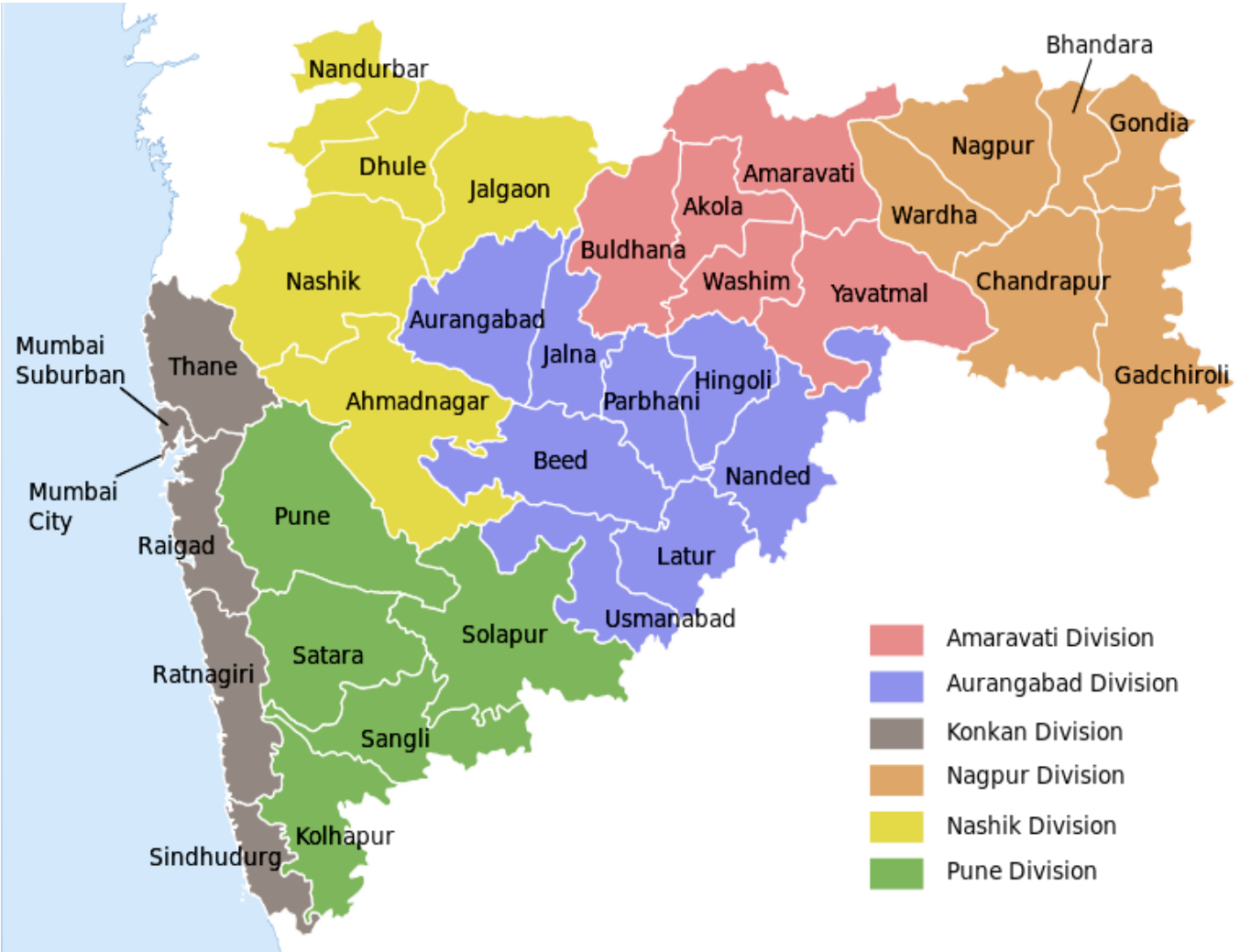

Figure 2: Administration map of Maharashtra State, India showing Divisions and Talukas (Sub Divisions) 